\title{
Understanding of Mono and Divalent Trace Elements Distribution in Soil from High Rainfall Area around Proposed Uranium Mining
}

\section{Jha SK*, Gothankar SS and Tripathi RM}

Health Physics Division, Bhabha Atomic Research Centre, Trombay, Mumbai, India

\begin{abstract}
The concentrations of trace elements $(\mathrm{K}, \mathrm{Ca}, \mathrm{Mn}, \mathrm{Fe}, \mathrm{Ni}, \mathrm{Cu}$ and $\mathrm{Zn})$ from different soil samples collected around propose Uranium mining KP Mawthabah (Domiasiat) located in high rainfall area were investigated with Energy Dispersive X-ray Fluorescence technique. Among the physical parameters $\mathrm{pH}$, moisture contents, organic matter and Cation Exchange Capacity (CEC) in soil indicated mild acidic to slightly alkaline nature of the soil and low water retention capacity. Depleted concentration of mono and divalent trace elements was observed when compared to the world average soil value.
\end{abstract}

Keywords: Soil; EDXRF; Trace element; High rainfall

\section{Introduction}

The soil, a main part of the terrestrial ecosystem, is a heterogeneous mixture of different organisms and minerals, organic, and organomineral substances present in three phases: solid, liquid and gaseous [1,2]. At the same time, soil is perhaps the most endangered component of our environment open to potential contamination by a variety of different pollutants arising from human activities such as industrial, agricultural, etc. $[3,4]$. Although the trace elements in soil are very important for the quality of soil and environment, excessive level of trace elements can cause pollution of waters, toxicity in plants, foods and ultimately in animals and humans that feed upon them. Mono and divalent trace elements have been the subject of particular attention because of their role in the biochemical cycling, mobility in the ecosystems. The trace element pollution depends on geochemical and biochemical properties of a given element. There is an increasing demand to understand the geochemical variation of mono and divalent trace elements to assess the quality of soil. Although considerable information exits on the trace elements in typical soil but there exit major gaps in behavior of latsol [5]. Information on native concentration of trace elements is important for determining if specific sites or large area has potential for concentration in view of proposed mining particularly in such a high rainfall area. Holmgreen et al. [6] have carried out a countrywide trace elements survey of agricultural soil in US and identified not only an area with natural high level of trace elements and also an agricultural area with possible contamination. Thus there is a need for information on native concentration of trace elements in an area subjected to high rainfall. On the other hand the exceedingly long period of continuous pedogenic weathering in this soil provides an opportunity for unique insight into mono and divalent trace elements geochemistry in freely drained acid soils. The study carried out with two objectives. The first is to inventory the mono and divalent trace elements in the highest rainfall area of the globe. The second is to better understand which among the commonly known divalent and mono valent elements accumulates or depletes in welldrained soil over extremely long periods of pedogenic weathering.

\section{Study area}

KP Mawthabah (Domiasiat) lies in a plateau state famous for its rain, mist and picturesque rolling hills and glens. It is bounded by the mighty Brahmaputra River in the north, Bangladesh plains in the South and West and plains of Assam in the North and East. Meghalaya lies between $25^{\circ} 47^{\prime} 26.10^{\prime \prime}$ North latitude and $89^{\circ} 45^{\prime} 92.45^{\prime \prime}$ East longitude. The Southern slopes of Khasi Hills receive maximum rainfall $(12,000$ mm year-1) in Sohra or Mawsynram and known as the highest rainfall area of the world [7]. Physiographically, the area forms a westerly sloping undulating hilly terrain with an average elevation of $1400 \mathrm{~m}$ above mean sea level. The climate is tropical and humid with temperature ranging between $2^{\circ}$ to $28^{\circ} \mathrm{C}$ with maximum during May-June and falling to $2^{\circ}$ in the month of January. Atomic Mineral Directorate for Exploration and Research (AMD) responsible for exploration of atomic mineral in the country discovered a large sandstone type near surface uranium ore deposits at KP Mawthabah (Domiasiat). The proposed uranium mining location is shown in Figure 1. Surface soil samples were collected over different seasons of the year from nine different locations namely

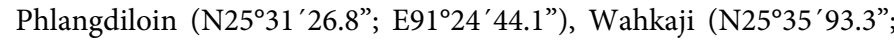
E91 $\left.{ }^{\circ} 26^{\prime} 24.5^{\prime \prime}\right)$, Umdohlun (N2537'91.1"; E91 $\left.{ }^{\circ} 27^{\prime} 06.1^{\prime \prime}\right)$, Domiasiat

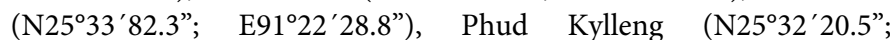
E91 $\left.{ }^{\circ} 20^{\prime} 60.8^{\prime \prime}\right)$, Phud Syngkai (N25 31'99.8”; E91 $21^{\circ}$ '08.2”), Nongbah

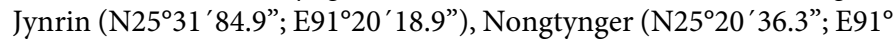

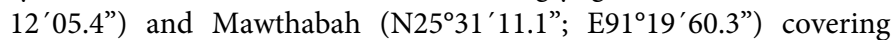
around $100 \mathrm{~km}^{2}$.

\section{Material and Method}

Soil samples were collected at depth of 0-0.2 $\mathrm{m}$ from all the locations in the study area using an Iwan Auger grab sampler during the period November and December of the year. Area was cleaned and any grass growing on the surface was removed. Plant, débris, Pebbles, stones etc. were removed from the collected samples [8]. Although area virtually receives very little human disturbance care was taken to have location $100 \mathrm{~m}$ away from paced roads or other potential source of trace metal contamination and several kilometers from any known industrial facilities. Conversations with landowner confirmed that sites have been partially cleared of native vegetation and have received no chemical fertilizers or other additives that could have introduced trace elements. A composite sample was prepared from each different location taking

*Corresponding author: Jha SK, Health Physics Division, Bhabha Atomic Research Centre, Trombay, Mumbai 400085, India, Tel: 91-22-2559291; E-mail: skjha@barc.gov.in

Received January 24, 2014; Accepted March 20, 2014; Published March 22 2014

Citation: Jha SK, Gothankar SS, Tripathi RM (2014) Understanding of Mono and Divalent Trace Elements Distribution in Soil from High Rainfall Area around Proposed Uranium Mining. J Environ Anal Chem 1: 109. doi:10.4172/jreac.1000109

Copyright: @ 2014 Jha SK, et al. This is an open-access article distributed under the terms of the Creative Commons Attribution License, which permits unrestricted use, distribution, and reproduction in any medium, provided the original author and source are credited. 


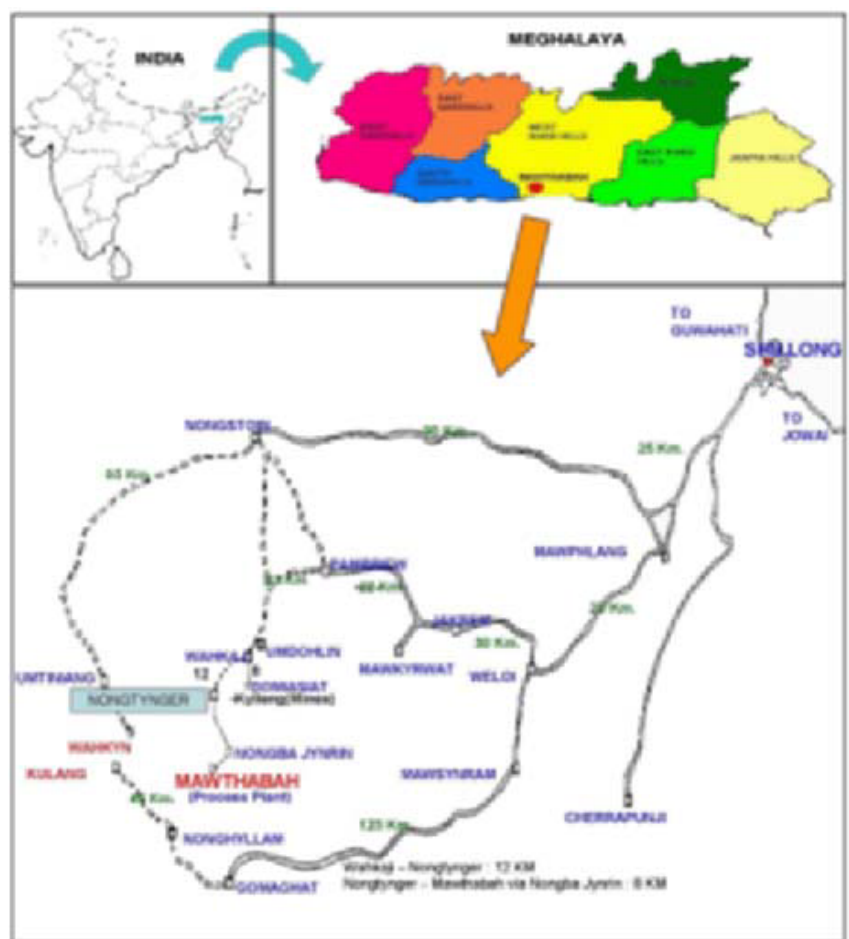

Figure 1: Surface soil samples were collected over different seasons of the year from nine different locations.

material from at least four different places and samples were stored in clean plastic bags. All the soil sampling locations were selected in well drained landscape position. Samples for total chemical analysis were air dried, crushed with a wooden roller, and sieved through a 2- $\mathrm{mm}$ plastic screen. The crushing and sieving operation was repeated until even the hardest soil aggregates were broken down, but we avoided crushing obvious rocks and indurated material when at all possible. About $20 \mathrm{~g}$ of the $<2-\mathrm{mm}$ soil material was then ground in an agate ball mill until all of the material passed through a $150-\mu \mathrm{m}$ disposable nylon screen, and then stored in glass vials with plastic cap liners. Soil $\mathrm{pH}$ was determined with an electrode in a 1:2.5 soil/water suspension, and Cation Exchange Capacity (CEC) was determined with the ammonium acetate leachate with the help of flame photometer $[9,10]$.

Quantative measurements of trace elements were carried out using Energy Dispersive X-ray Fluorescence (EDXRF) technique (EDXRF Model 3600 -Jordan Valley Make). The pallets were prepared by mixing 1 gram of sample and 1 gram of binding material (cellulose powder) under 10 metric ton hydraulic pressure. Pallets are mounted in the sample holder, samples were analyzed using suitable transmission filters to remove primary beam continuum, and to provide substantially monochromatic excitation line. The samples were analysed along with Reference standards Soil-7 and the concentration of different elements in the sample were estimated by comparative method. All the elements were determined through their K X-rays [11] and the results were based on five measurements of each sample.

\section{Results and Discussion}

Among the physical parameters $\mathrm{pH}$, moisture content, organic matter and CEC of soil samples collected from different locations are given in Table 1. The soils of Meghalaya are dominated by the laterite group. The hilly soils are mostly derived from gneissic complex parent materials. The soils are fairly deep to very deep and ranging from light to medium sandy loam to clay loam in texture as reflected by low cation exchange capacity. The measurement of organic matter in the soil indicates a higher organic content. The observed value ranges from 0.33 to $6.05 \%$. The higher organic matter indicates that soil is less susceptible to compaction and in turns high aeration. The moisture content varies from $13.93 \%$ to $18.70 \%$ indicating low water holding capacity. The soils are mild acidic to slightly alkaline in reaction with $\mathrm{pH}$ ranging $5.67 \pm 0.5$ to $7.52 \pm 0.18$. The CEC was found to vary between $8.0 \pm$ 0.8 to $14.0 \pm 0.68 \mathrm{meq} / 100 \mathrm{~g}$ of soil. The low CEC observed in the soil reflects the low water holding ability. The studied physical parameters indicate that the soil was well aerated as it is superficial layer. Table 2 gives the results of the quality control exercise carried out using the certified reference standard Soil 7 obtained from International Atomic Energy Agency (IAEA).

Soil is a natural medium for plant growth. In addition to anchoring the plant, soil also acts as a reservoir for plant nutrients. The trace elements like Iron (Fe), Zinc ( $\mathrm{Zn})$, Potassium (K), Calcium $(\mathrm{Ca})$, Copper $(\mathrm{Cu})$, Nickel $(\mathrm{Ni})$ and Manganese $(\mathrm{Mn})$ are considered essential because, in their absence or deficiency, the plant will not be able to flourish and complete its life cycle. All the essential plant nutrients except carbon, hydrogen and oxygen are absorbed by the plant roots from the soil. The result of analysis of trace elements in soil collected from nine locations around the proposed mining site at KPM Mawthabah, Domiasiat are presented in Table 3 along with range and mean of world soil [12]. The maximum value of $K$ was observed at Wahkaji (7343 $\mathrm{mg} \mathrm{kg}^{-1}$ ) and minimum value was observed at Umdohlun (4213 mg kg-1) whereas the maximum value of $\mathrm{Ca}\left(2907 \mathrm{mg} \mathrm{kg}^{-1}\right)$ was observed at Nongtynger and minimum value $\left(390 \mathrm{mg} \mathrm{kg}^{-1}\right)$ observed at Wahkaji. The maximum value of $\mathrm{Cu}\left(25.6 \mathrm{mg} \mathrm{kg}^{-1}\right)$ was observed at Domiasiat and minimum value was observed at Nongbahjyrin (12.9

\begin{tabular}{|l|l|l|l|l|l|}
\hline $\begin{array}{l}\text { Sr. } \\
\text { No. }\end{array}$ & Location & pH & $\begin{array}{l}\text { Moisture } \\
\text { Content (\%) }\end{array}$ & $\begin{array}{l}\text { Organic } \\
\text { matter } \\
(\%)\end{array}$ & $\begin{array}{l}\text { Cation Exchange } \\
\text { Capacity (CEC) } \\
\text { (meq /100g of soil) }\end{array}$ \\
\hline 1 & Phlangdiloin & $6.09 \pm 0.69$ & 18.70 & 1.75 & $8 \pm 0.90$ \\
\hline 2 & Wahkaji & $6.04 \pm 0.72$ & 14.38 & 4.87 & $8 \pm 0.80$ \\
\hline 3 & Umdohlun & $6.30 \pm 0.35$ & 15.23 & 4.54 & $10 \pm 0.75$ \\
\hline 4 & Domiasiat & $7.05 \pm 0.23$ & 13.93 & 5.71 & $10 \pm 0.75$ \\
\hline 5 & Phud Kylleng & $5.77 \pm 0.20$ & 18.10 & 6.05 & $10 \pm 0.75$ \\
\hline 6 & Phud Syngkai & $7.00 \pm 0.22$ & 15.78 & 4.20 & $10 \pm 0.75$ \\
\hline 7 & Nongbah Jynrin & $7.52 \pm 7.18$ & 12.71 & 3.70 & $8 \pm 0.9$ \\
\hline 8 & Mawthabah & $6.11 \pm 0.41$ & 13.91 & 4.37 & $12 \pm 0.70$ \\
\hline 9 & Nongtynger & $5.67 \pm 0.50$ & 17.74 & 0.34 & $14 \pm 0.68$ \\
\hline
\end{tabular}

Table 1: Different parameters of corresponding soil samples.

\begin{tabular}{|l|l|l|l|l|}
\hline Sr. No. & Element & $\begin{array}{l}\text { Our Measured } \\
\text { Values }\end{array}$ & $\begin{array}{l}\text { Reported Certified } \\
\text { Values }\end{array}$ & Accepted Range \\
\hline 1 & $\mathrm{~K}(\%)$ & $1.23 \pm 0.03$ & 1.21 & $1.13-1.27$ \\
\hline 2 & $\mathrm{Ca}(\%)$ & $1.7 \pm 0.04$ & 16.3 & $15.7-17.4$ \\
\hline 3 & $\mathrm{Mn}$ & $623 \pm 18$ & 631 & $604-650$ \\
\hline 4 & $\mathrm{Fe}(\%)$ & $2.59 \pm 0.04$ & 2.57 & $2.52-2.63$ \\
\hline 5 & $\mathrm{Ni}$ & $29 \pm 3.0$ & 26 & $21-37$ \\
\hline 6 & $\mathrm{Cu}$ & $13 \pm 1.0$ & 11 & $9-13$ \\
\hline 7 & $\mathrm{Zn}$ & $108 \pm 5.0$ & 104 & $101-113$ \\
\hline
\end{tabular}

Table 2: Analysis of certified reference standard IAEA-Soil-7 (mg.kg-1 unless indicated otherwise). 
Citation: Jha SK, Gothankar SS, Tripathi RM (2014) Understanding of Mono and Divalent Trace Elements Distribution in Soil from High Rainfall Area around Proposed Uranium Mining. J Environ Anal Chem 1: 109. doi:10.4172/jreac.1000109

$\left.\mathrm{mg} \mathrm{kg}^{-1}\right)$ whereas the maximum value of $\mathrm{Ni}\left(14.9 \mathrm{mg} \mathrm{kg}^{-1}\right)$ was observed at Wahkaji and minimum value was observed at Phud Syngkai $(2.4 \mathrm{mg}$ $\left.\mathrm{kg}^{-1}\right)$. The maximum value of $\mathrm{Zn}$ was observed at Mawthabah $(36.5 \mathrm{mg}$ $\left.\mathrm{kg}^{-1}\right)$ and minimum value observed at Domiasiat $\left(14.7 \mathrm{mg} \mathrm{kg}^{-1}\right)$. The concentration of trace elements for the soil samples at the different locations showed lower values compared to the levels reported for the average world soil value [12-14]. Figures 2 and 3 presents the concentration ratio of trace elements in soil from study area to the reported world average soil value. The ratio of $\mathrm{Zn}, \mathrm{K}, \mathrm{Ca}$ and $\mathrm{Ni}$ varies from 0.03 to 0.5 whereas ratio of $\mathrm{Fe}, \mathrm{Cu}$ and $\mathrm{Mn}$ varies from 0.5 to $<1$ except $\mathrm{Fe}$ at Phudkylleng and $\mathrm{Cu}$ at Domiasiat. A common feature of all the elements that occur in low concentration in all the soil collected from different locations around proposed mining location compared to the soil worldwide was that they are monovalent or divalent cations in most stable oxidation state in acid well aerated soil. The elements $\mathrm{K}$, $\mathrm{Ca}, \mathrm{Ni}, \mathrm{Cu}, \mathrm{Zn}$ were lost during long period of weathering that could be due to various reasons. As monovalent or divalent cations, elements cannot be incorporated in the structure of kaolinite, gibbsite, hematite or goethite without producing a charge imbalance. Thus $\mathrm{K}, \mathrm{Ca}, \mathrm{Ni}, \mathrm{Cu}$ and $\mathrm{Zn}$ tend to be excluded from the most stable minerals in weathered soil in high rainfall area. Although transition elements $\mathrm{Ni}, \mathrm{Cu}$ and $\mathrm{Zn}$ can be strongly sorbed by Fe oxides, this sorption is $\mathrm{pH}$ dependent and weak at $\mathrm{pH}<6$ [14]. Thus specific adsorption is not a major factor in the long term persistence of these elements in soil.
Although $\mathrm{Mn}$ and Fe share similarity in redox chemistry [15] obtained values and ratio (Table 3 and Figure 3) indicated that $\mathrm{Mn}$ does not accumulate in the acid, freely drained. Under the mild acidic and slightly alkaline conditions of studied soils $(\mathrm{pH}), \mathrm{Mn}$ can be reduced easily even under oxic conditions, whereas Fe reduction requires suboxic or anoxic conditions [15]. The higher Fe is rarely, if ever, reduced in these soils and Fe-oxide minerals such as goethite and hematite are stable and accumulate. Manganese, however, shuttles easily between insoluble $\left(\mathrm{Mn}^{3+}, \mathrm{Mn}^{4+}\right)$ oxide minerals and soluble $\mathrm{Mn}^{2+}$ [16] reflected by little variation in the $\mathrm{Mn}$ ratio with world average soil value (Figure 3).

\section{Conclusion}

The study was carried out around uranium mineralization zone situated in a high rainfall area of India. The physical parameters $\mathrm{pH}$, moisture content, organic matter and CEC of soil indicated mild acidic to slightly alkaline nature of the soil and low water retention capacity. The soil of the study area showed high organic matter contents which can be an important indicator of nitrogen supplying power. Depleted concentration of mono and divalent trace elements was observed when compared to the world average soil value. The Ca was found most depleted whereas Mn and Fe showed least depleted pattern. These soils can support a continuous cultivation of field crop.

\begin{tabular}{|c|c|c|c|c|c|c|c|c|c|c|c|c|c|c|}
\hline \multirow[t]{3}{*}{ Location } & \multicolumn{14}{|c|}{ Elemental concentration $\left(\mathrm{mg} \mathrm{kg}^{-1}\right)$} \\
\hline & \multicolumn{2}{|c|}{$\mathrm{Fe}(\%)[12]$} & \multicolumn{2}{|c|}{ Zn [13] } & \multicolumn{2}{|c|}{ K [10] } & \multicolumn{2}{|c|}{$\mathrm{Ca}[10]$} & \multicolumn{2}{|c|}{$\mathrm{Cu}[13]$} & \multicolumn{2}{|c|}{ Ni [13] } & \multicolumn{2}{|c|}{ Mn [13] } \\
\hline & Range & Mean & Range & Mean & Range & Mean & Range & Mean & Range & Mean & Range & Mean & Range & Mean \\
\hline World soil $^{*}$ & $0.2-55$ & 4.00 & $17-236$ & 67.0 & - & 14000 & - & 13700 & $6-80$ & 24.0 & $6-92$ & 24.0 & $80-1315$ & 558.0 \\
\hline Phlangdilion & $1.0-3.6$ & 2.41 & $15.5-36.1$ & 24.8 & $5000-6213$ & 5843 & $712-998$ & 858 & $14.5-31.2$ & 18.8 & $3.9-13.2$ & 7.8 & $316.2-487.2$ & 400.7 \\
\hline Wahkaji & $1.1-3.5$ & 2.53 & $8.8-28.4$ & 22.1 & $5153-8615$ & 7343 & $214-520$ & 390 & $11.8-21.8$ & 13.6 & $2.9-7.2$ & 5.1 & $335-532.2$ & 431.8 \\
\hline Umdohlun & $2.1-4.8$ & 3.01 & $11.1-32.0$ & 17.1 & $3654-4529$ & 4213 & $211-1230$ & 534 & $10.6-26.9$ & 16.0 & $3.8-19.0$ & 10.5 & $377.1-495.6$ & 440.4 \\
\hline Domiasiat & $1.1-3.7$ & 2.61 & $6.3-21.4$ & 14.7 & $2189-5592$ & 4704 & $341-1278$ & 735 & $13.5-54.1$ & 25.6 & $1.0-9.9$ & 4.7 & $411-580.8$ & 499.3 \\
\hline Phud Kylleng & $2.3-7.9$ & 4.45 & $10-38.2$ & 19.4 & $4055-5360$ & 4551 & $264-1274$ & 660 & $12-18.9$ & 15.1 & $1.8-14.7$ & 5.5 & $404.9-515.8$ & 450.8 \\
\hline Phud Syngkai & $1.1-5.3$ & 2.85 & $11.8-53.2$ & 27.6 & $4789-5879$ & 5214 & $849-1849$ & 1201 & $11.2-21.1$ & 13.8 & $1.0-3.8$ & 2.4 & $411.2-527.8$ & 501.5 \\
\hline Nongbah Jynrin & $1.0-4.5$ & 2.41 & $10.8-33.0$ & 19.8 & $5687-6877$ & 6240 & $113-910$ & 417 & $10.1-17.8$ & 12.9 & $2.1-5.0$ & 3.6 & $409.5-532.6$ & 478.6 \\
\hline Mawthabah & $2.3-4.9$ & 3.55 & $22.4-51.2$ & 36.5 & $3126-5976$ & 5094 & $205-1186$ & 504 & $10.1-18.8$ & 15.1 & $2.7-6.8$ & 4.4 & $328.8-519.5$ & 428.8 \\
\hline Nongtyngnger & $2.4-5.6$ & 3.52 & $10.2-21.1$ & 16.5 & $4877-5866$ & 5442 & $573-8332$ & 2907 & $13.6-20.2$ & 16.3 & $3.15-7.0$ & 5.2 & $347.1-568.6$ & 435.2 \\
\hline
\end{tabular}

Table 3: Trace elements distribution in soil samples.

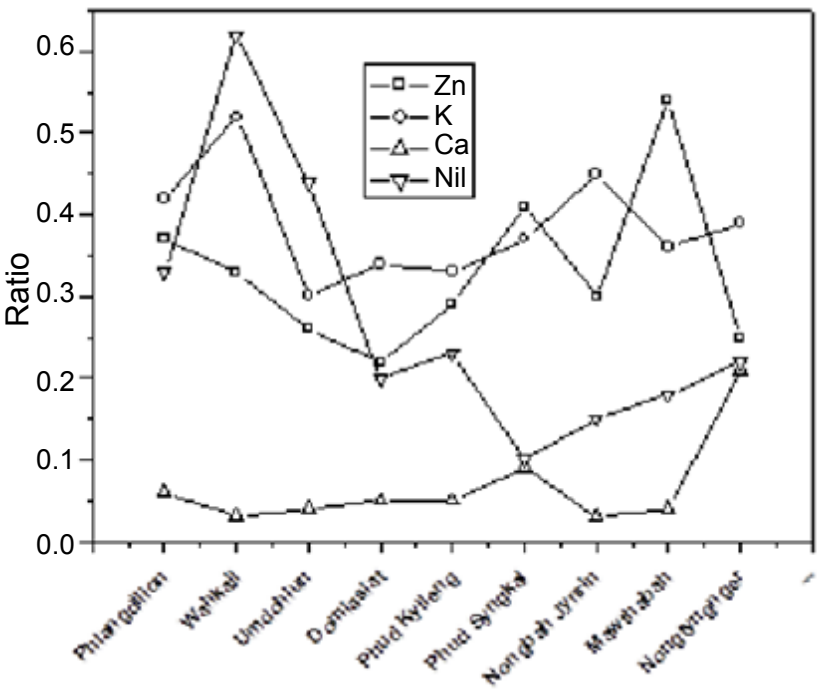

Figure 2: Concentration ratio of trace elements in soil from study area.

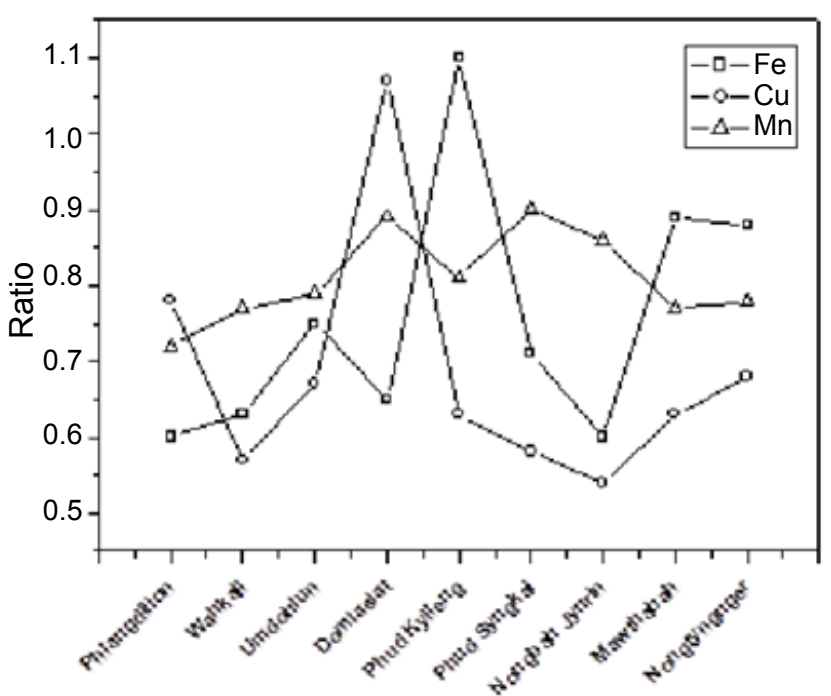

Figure 3: Concentration ratio of trace elements in soil from study area. 
Citation: Jha SK, Gothankar SS, Tripathi RM (2014) Understanding of Mono and Divalent Trace Elements Distribution in Soil from High Rainfall Area around Proposed Uranium Mining. J Environ Anal Chem 1: 109. doi:10.4172/jreac.1000109

\section{References}

1. CoÅŸkun M, Steinnes E, Frontasyeva MV, Sjobakk TE, Demkina S (2006) Heavy metal pollution of surface soil in the Thrace region, Turkey. Environ Monit Assess 119: 545-556

2. Kabata-Pendias A (2004) Geoderma 122: 143.

3. Djingova R, Kuleff I (2007) Trace elements-Their Distribution and Effects in the Environment, Elsevier, Amsterdam.

4. Morto-Bermea O, Hernández Alvarez E, Gaso I, Segovia N (2002) Heavy metal concentrations in surface soils from Mexico City. Bull Environ Contam Toxicol 68: 383-388.

5. Buol SW, Eswaran H (2000) Oxisols. Adv Agr 68: 151.

6. Holmgren GGS, Meyer MW, Chaney RL, Daniels RB (1993) J Environ Qual 22: 335 .

7. Jha SK, Gothankar S, Iongwai PS, Kharbuli B, War SA, et al. (2012) IIntake of ${ }^{238} \mathrm{U}$ and ${ }^{232} \mathrm{Th}$ through the consumption of foodstuffs by tribal populations practicing slash and burn agriculture in an extremely high rainfall area. $J$ Environ Radioact 103: 1-6.

8. Marques J, Schulze DG, Curi N, Mertzman SA (2004) Geoderma 119
9. Hesse PR (1971) A text book of soil chemical analysis, CBS publishers and distributor, Delhi.

10. Kai-hua L, Shao-hui XU, Ji-chun W, Shu-hua JI, Qing L (2011) Agricultural Sciences in China 10: 1246.

11. Jha SK, Chavan SB, Pandit GG, Negi BS, Sadasivan S (2002) Behaviour and fluxes of trace and toxic elements in creek sediment near Mumbai, India. Environ Monit Assess 76: 249-262.

12. Bowen HJM (1979) The environmental chemistry of the elements, Academic Press, London, New York.

13. Shahabuddin M, Hossain MD, Hossain SM, Monzurul HM, Mamun MM et al. Soil Contamination in Nuclear Reactor Surrounding Areas in Savar, Bangladesh using Instrumental Neutron Activation Analysis Method. Int Journal of Env Sci 1: 282-295.

14. Marques J, Schulze DG, Curi N, Mertzman SA (Geoderma) 121.

15. Burns G (1993) Mineralogical Applications of Crystal Field Theory, Cambridge Univ. Press, New York.

16. Guest CA, Schulze DG, Thompson IA, Huber DM (2002) Correlating Manganese X-Ray Absorption Near-Edge Structure Spectra with Extractable Soil ManganeseSoil Sci Soc Am J 66: 1172 